This is a revised personal version of the text of the final journal article, which is made available for scholarly purposes only, in accordance with the journal's author permissions. The full citation is:

Bárbara Rincón, Sonia Heaven, Andrew M. Salter \& Charles J. Banks (2016):

Anaerobic digestion of spring and winter wheat: Comparison of net energy yields, Journal of Environmental Science and Health, Part A, DOI: 10.1080/10934529.2016.1198634

\title{
Anaerobic digestion of spring and winter wheat: Comparison of net energy yields
}

BÁRBARA RINCÓN ${ }^{1,2 *}$, SONIA HEAVEN ${ }^{2}$, ANDREW M. SALTER ${ }^{2}$ and CHARLES J. BANKS ${ }^{2}$

${ }^{1}$ Department of Food Biotechnology, Instituto de la Grasa (CSIC), Sevilla, Spain.

${ }^{2}$ Faculty of Engineering and the Environment, University of Southampton, Southampton, UK

\begin{abstract}
*Address correspondence to Bárbara Rincón, Instituto de la Grasa (CSIC), Campus Universidad Pablo de Olavide - Edificio 46, Ctra. de Utrera, km. 1 - 41013, Sevilla, Spain; Phone: +34 954611550 (Ext. 223); Fax: +34 95 4616790; E-mail: brlloren@cica.es
\end{abstract}

\begin{abstract}
Anaerobic digestion of wheat was investigated under batch conditions. The paper compares the potential net energy yield between a Winter wheat (sown in the autumn) and a Spring wheat (sown in the spring) grown in the same year and harvested at the same growth stage in the same farm. The Spring wheat had a slightly higher biochemical methane potential and required lower energy inputs in cultivation, but produced a lower dry biomass yield per hectare that resulted in Winter wheat providing the best overall net energy yield. The difference was small both varieties gave a good net energy yield. Spring sowing may also offer the opportunity for growing an
\end{abstract}


additional over-winter catch crop for spring harvest, thus increasing the overall biomass yield per hectare, with both crops being potential digester feedstocks.

Keywords: Energy crop, renewable energy production, anaerobic processes, biodegradation, environmental preservation.

\section{Introduction}

Whole crop cereals can be used as feedstock for second generation biofuel production through anaerobic digestion $(\mathrm{AD})$. $\mathrm{AD}$, classified within the biochemical conversion process, is a robust process and is widely applied. ${ }^{[1]}$ The biogas produced through AD could be valorised energetically in a combined heat and power installation for the simultaneous generation of heat and electricity. These installations offer electrical efficiencies of $33 \%$ and a thermal efficiency of $45 \% .{ }^{[2]}$ Methane yields for energy crops are within the range of $0.39-0.41 \mathrm{~m}^{3} / \mathrm{kg}$ organic dry solids for sugar beet, 0.32 $0.34 \mathrm{~m}^{3} / \mathrm{kg}$ organic dry solids for triticale, $0.23-0.30 \mathrm{~m}^{3} / \mathrm{kg}$ organic dry solids for sunflower and $0.30-0.41 \mathrm{~m}^{3} / \mathrm{kg}$ organic dry solids for rye grain. ${ }^{[3]}$

Renewable resources will play a crucial role in the current $\mathrm{CO}_{2}$ mitigation policy. In this regard, energy from biomass and waste is seen as one of the most dominant future renewable energy sources, since it can provide continuous power generation. ${ }^{[2]}$ Member states of the European Union are supposed to set up Renewable Energy Plans to achieve that $20 \%$ of the total energy production be from renewable origin by $2020 .{ }^{[4]}$

One of the main advantages of using energy crops for anaerobic digestion is that energy crops can be easily stored so energy can be produced throughout the year and/or when the demand and/or price for energy are highest. ${ }^{[5]}$ The most usual storage process is ensiling. Ensilig methods, adapted from the feed sector, are suitable storage methods to preserve fresh crops throughout the year for biogas production. ${ }^{[6]}$ Ensiling is normally 
carried out in anaerobic conditions where the endogenous microflora generates acids. A combination of anaerobic conditions and acidity protects the forage from the proliferation of deleterious bacteria and fungi and avoid the carbohydrate loses. ${ }^{[7,8]}$ During ensiling and storage the changes in chemical composition compensate for silage losses. For authors like Herrmann et al. ${ }^{[9]}$, ensiling resulted in an increase of $1-18 \%$ in methane yield referred to organic dry matter. The $\mathrm{pH}$ achieved, the low amounts of volatile fatty acids formed and the limited degradation of protein in ensiled crops indicate the ensiling process successful in many crops as: crop maize, fibre hemp and faba bean. In some crops ensiling can even improve the methane production, ensiling of hemp increased methane production by more than $50 \%$ compared to fresh hemp. ${ }^{[6]}$ Another treatment used for crops conservation is the Alkalage treatment which uses ammonia gas as the preserving agent. Alkalage preservation is applied to forage materials with a high dry matter content (65-85\%) and allows extension of the harvest period by up to 30 days.

The biogas yield per hectare of crop is affected by the specific methane yield of the crop material and the amount of dry organic matter harvested. Both of these parameters change with growth stage at harvest, and a number of papers have reported the effects of growth stage on specific methane production and/or biogas yield per hectare. ${ }^{[8,10-13]}$ The volatile solids yield per hectare was notably influenced by the differences in climate and soil conditions between locations, being in the ranges of 1.4-3.0 t ha-1 and 0.3-1.7 tha1 for holstebro and aabenraa, respectively. ${ }^{[14]}$

Wheat (Triticum aestivum L. 42n) can be categorised into two types, Winter and Spring wheat, according to its vernalisation requirement. Vernalisation involves exposure to a temperature of $1-3{ }^{\circ} \mathrm{C}$ for period of approximately six weeks, and is necessary in some plant varieties in order to initiate flowering. ${ }^{[15]}$ Without such a period, cereal crops 
requiring vernalisation keep tillering (i.e. producing multiple stems), and do not enter the stem elongation stage or produce seed heads. This results in no grain for a seed crop, or a considerably reduced biomass yield if harvested as whole crop. Winter wheat is sown in late autumn so that it can produce enough biomass to survive the cold period, ideally reaching the second (tillering) stage before lower temperatures restrict growth. Spring wheat does not require vernalisation and so is sown in the spring, after the frost period. Both types of wheat flower in early summer and are harvested at a similar time in autumn, and both can be used for grain production or harvested as whole crop.

The current research compared the biochemical methane potential (BMP) value of a Spring wheat with that of a Winter wheat grown in the same year at the same location in north-west England and harvested at the same growth stage. BMP data and biomass yields were then used to calculate potential energy yields per hectare, taking into account the energy requirements for crop production in each case. This work fills a gap in existing knowledge, as no comparison of the energy yields from Spring and Winter wheat has previously been published.

\section{Materials and methods}

\section{Substrate and Inoculum}

Two samples of Spring wheat (Wheat 1 and 2) were tested, both taken from a single variety grown in the same field and harvested at the same time in the early to soft dough stage. Wheat 1 was treated with an experimental additive to promote hydrolysis and acidogenesis, which was applied during the harvesting process, while Wheat 2 was untreated. Both wheats were then ensiled in bulk for $\sim 3$ months, after which a sample of $\sim 100 \mathrm{~kg}$ was collected and taken to the laboratory where it was stored at $-18{ }^{\circ} \mathrm{C}$. Before 
use in the BMP test sub-samples of $5 \mathrm{~kg}$ were defrosted and milled to a particle size of 0.5-1.5 cm, to ensure homogeneity and a good inoculum-substrate mass transfer.

Winter wheat used for comparison was a single variety sown at the same time (autumn) and harvested at 3 different stages in its growth: medium milk (A); soft dough (B) and Caryopsis (C) stages. The two early harvested wheats (A and B) were ensiled whilst the later harvested material $(\mathrm{C})$ with a higher dry matter content was treated by the alkalage process.

Inoculum for the BMP tests was taken from a mesophilic anaerobic digester treating municipal wastewater bio-solids (Millbrook, Southampton, UK). Before use, the inoculum was sieved through a $1 \mathrm{~mm}$ mesh to remove large particles and grit.

\section{BMP Assay}

BMP tests were performed in continuously stirred tank reactors (CSTR) with a working volume of $1.4 \mathrm{~L}$, maintained at $37 \pm 1{ }^{\circ} \mathrm{C}$ in a thermostatic water bath and stirred at 40 rpm. Biogas was collected by displacement of a $75 \%$ saturated sodium chloride solution acidified to $\mathrm{pH} 2$ in calibrated glass cylinders. The height of the solution in the collection cylinder was recorded by a headspace pressure sensor and logged at 5-minute intervals, with manual readings to check calibration. Vapour pressure and salt solution density were taken into account in correction of gas volumes to standard temperature and pressure (STP) of $0{ }^{\circ} \mathrm{C}$ and $101.325 \mathrm{kPa} .{ }^{[16]}$ Samples for gas composition analysis were taken from the cylinders each time they were refilled, at intervals of no more than 7 days.

Each wheat sample was tested in triplicate against triplicate control digesters without substrate addition. The reactors were filled with $1400 \mathrm{~g}$ wet weight (WW) of sieved inoculum and left overnight to reduce the residual available organic matter. Each reactor 
was then fed with the required amount of the tested wheat to give an inoculum-tosubstrate (I:S) ratio of 2:1 on a volatile solids basis. $1.4 \mathrm{ml}$ of trace element solution was also added. ${ }^{[8]}$ The test was run until there was no difference in gas production between the control and test reactors, giving a duration of 79 days. Positive controls consisting of a maize sample taken from a single batch of known BMP were run. Spring wheat was run in parallel with the Winter wheat BMP tests.

\section{Analytical Methods}

Total (TS) and volatile solids (VS) were measured according to Standard Methods 2540 B and E. ${ }^{[17]} \mathrm{pH}$ was determined using a Jenway 3010 meter (Bibby Scientific Ltd, UK) with a combination glass electrode calibrated in buffers at $\mathrm{pH}$ 4.0, 7.0 and 9.2 (Fisher Scientific, UK). Alkalinity was measured by titration with $0.25 \mathrm{~N} \mathrm{H}_{2} \mathrm{SO}_{4}$ to $\mathrm{pH} 4.3$. Total Kjeldahl Nitrogen (TKN) and ammonia were determined using a Kjeltech block digestion and steam distillation unit according to the manufacturer's instructions (Foss Ltd, UK). A CAL2k-ECO bomb calorimeter (CAL2k, South Africa) was used to measure calorific value $(\mathrm{CV})$. Biogas composition was analysed using a Varian $\mathrm{CP}$ 3800 gas chromatograph with a thermal conductivity detector and a gas sampling loop, with argon as the carrier gas at a flow of $50 \mathrm{~mL} \mathrm{~min}^{-1}$. The GC was fitted with a Hayesep C column and a molecular sieve 13 x (80-100 mesh) operating at $50{ }^{\circ} \mathrm{C}$. Calibration was against a standard gas containing $35 \% \mathrm{CO}_{2}$ and $65 \% \mathrm{CH}_{4}(\mathrm{BOC}, \mathrm{UK})$. Samples for volatile fatty acid (VFA) analysis were prepared by centrifuging at 13000 rpm for 10 min (model 5417C, Eppendorf, Germany) and acidifying the centrifugate to $10 \% \mathrm{v} / \mathrm{v}$ with formic acid. VFA content was measured by gas chromatography (model

GC-2010, Shimazdu, Tokyo, Japan), using a flame ionization detector and an FFAP capillary column (SGE Europe Ltd, UK) with helium as the carrier gas at a flow of 
$190.8 \mathrm{~mL} \mathrm{~min}^{-1}$. The GC oven temperature increased from 60 to $210{ }^{\circ} \mathrm{C}$ in $15 \mathrm{~min}$, with a final hold time of $3 \mathrm{~min}$. Injector and detector temperatures were 200 and $250{ }^{\circ} \mathrm{C}$, respectively.

Further characterisation was carried out on samples air dried to constant weight and then milled to a particle size $\leq 0.5 \mathrm{~mm}$ in a micro-hammer mill (Glen Creston Ltd, UK). Air-dried material was used for elemental analysis $(\mathrm{C}, \mathrm{H}, \mathrm{N})$ according to the manufacturer's instructions (Flash EA-1112, Thermo Finnigan, UK), with L-Aspartic Acid, Atropine and Nicotinamide as standards. Phosphorus was measured by the ascorbic acid method 4500-PE, using a Cecil 3000 Series Spectrophotometer (Cecil Instruments, UK). ${ }^{[17]}$ For metals determination a nitric acid extract was prepared by microwave digestion (Model MARS X ${ }^{\mathrm{R}}, \mathrm{XP}-1500$ Plus, CEM Corporation). The extract was filtered and diluted to $50 \mathrm{~mL}$ with deionised water (Milli-Q Gradient, Millipore, $\mathrm{UK}$ ), and used for determination of $\mathrm{Cd}, \mathrm{Cr}, \mathrm{Cu}, \mathrm{K}, \mathrm{Ni}, \mathrm{Pb}$, and $\mathrm{Zn}$ in an atomic absorption spectrometer (Spectr AA-200, Varian, USA) calibrated against stock standards (Sigma Aldrich, UK; Fisher Scientific, UK).

\section{Energy Balance}

The Buswell equation was used to calculate the theoretical methane yield of the samples based on elemental composition, with $\mathrm{O}$ estimated by assuming $\mathrm{C}+\mathrm{H}+\mathrm{O}+\mathrm{N}=99.5 \%$ on a VS basis. ${ }^{[18]}$ Theoretical CV was calculated using the Du Long equation according to the Combustion File 24 method. ${ }^{[19]}$ The methane yield of the crop was calculated from the methane potential of the material multiplied by the crop biomass yield. Direct and indirect energy requirements for crop production were estimated using the methods of

Salter and Banks with data from KTBL, Berglund and Börjesson and Audsley et al. ${ }^{[20-}$ ${ }^{23]}$ Direct energy inputs consisted of the fuel used in typical crop operations for the two 
types of wheat: ploughing (23.2 $\left.\mathrm{L} \mathrm{ha}^{-1}\right), 2 \mathrm{x}$ seedbed preparation $\left(5.7 \mathrm{~L} \mathrm{ha}^{-1}\right.$ operation $\left.^{-1}\right)$, drilling (2.8 $\left.\mathrm{L} \mathrm{ha}^{-1}\right)$, rolling (1.1 $\left.\mathrm{L} \mathrm{ha}^{-1}\right), 2$ (Spring wheat) or 3 (Winter wheat) $\mathrm{x}$ spraying (0.9 $1 \mathrm{ha}^{-1}$ operation $\left.^{-1}\right), 2$ (Spring wheat) or 3 (Winter wheat) $\mathrm{x}$ fertiliser application using a trailed hose $\left(3.6 \mathrm{~L} \mathrm{ha}^{-1}\right.$ operation $\left.^{-1}\right)$ and harvesting $\left(29.7 \mathrm{~L} \mathrm{ha}^{-1}\right) .{ }^{[21]}$ The energy value of diesel was taken as $35.7 \mathrm{MJ} \mathrm{L}^{-1}{ }^{[24]}$ Indirect energy inputs comprised those for production and maintenance of equipment. ${ }^{[23]}$ Fertiliser input was assumed to be in the form of cattle slurry mixed with washwater from yards and dairies, to meet total nitrogen $(\mathrm{N})$ requirements of $180 \mathrm{~kg} \mathrm{ha}^{-1}$ for Winter wheat and $150 \mathrm{~kg} \mathrm{ha}^{-1}$ for Spring wheat (personal communication, P. King).

\section{Results and discussion}

\section{Characterisation}

Spring wheat, Winter wheat and inoculum characteristics are shown in Table 1. Winter wheat used for comparison was a single variety sown at the same time (autumn) and harvested at 3 different stages in its growth: medium milk (A); soft dough (B) and Caryopsis (C) stages. The two early harvested wheats (A and B) were ensiled whilst the later harvested material (C) with a higher dry matter content than A and B was treated by the alkalage process.

Spring wheat used was a single variety grown in the same year at the same location than winter wheat. The physico-chemical properties of Wheat 1 and 2 were closely similar, apart from slight differences in measured concentrations of $\mathrm{Ni}$ and $\mathrm{Cr}$. The $\mathrm{C}: \mathrm{N}$ ratio for Spring wheat was $\sim 23: 1$, within the recommended range for anaerobic digestion of between 20 and 40:1. The moisture content of the Spring wheat was around $60 \%$, considerably higher than the value reported for Winter wheat at the same soft dough stage (Wheat B, Table 1). Crop yields at the soft dough growth stage were 13.0 tonnes 
$\mathrm{TS} \mathrm{ha}^{-1}$ for Spring wheat and 14.6 tonnes TS ha ${ }^{-1}$ for Winter wheat (pers. comm., P. King).

\section{Quality assurance}

Figure 1 shows the cumulative net specific methane yield in the BMP test for Spring wheat, obtained by deducting the methane production in the controls from that in the test digesters. The replicates for Wheat 1 (Wheat 1.1., Wheat 1.2 and Wheat 1.3) showed good agreement throughout. For Wheat 2 (Wheat 2.1., Wheat 2.2 and Wheat 2.3) the final values were also in very good agreement, despite slightly lower cumulative totals for Wheat 2.1 and 2.3 between days $15-55$ of the test: the reason for this feature is unknown. Residual VS concentrations in the digestate were $22 \pm 3,21 \pm 1$ and $18 \pm 1 \mathrm{~g} \mathrm{VS} \mathrm{kg}^{-1} \mathrm{WW}$ for Wheat 1 , Wheat 2 and control digesters respectively. Gas production curves for the test showed smooth profiles with no signs of inhibition. The cumulative gas yields for blank and positive controls were in agreement with typical exponential curves obtained for different crops. At the end of the run the $\mathrm{pH}$ was 7.9 and 7.7 and alkalinity was 12 and $11 \mathrm{~g} \mathrm{CaCO}_{3} \mathrm{~L}^{-1}$ in the test and control digesters respectively, confirming suitable test conditions.

BMP values obtained for Spring wheat were $0.351 \pm 0.005$ and $0.361 \pm 0.004 \mathrm{~L} \mathrm{CH}_{4} \mathrm{~g}^{-1}$ VS added for Wheat 1 and 2, respectively. These are in the middle of the range typically reported for wheat, maize and similar energy crops, triticale. ${ }^{[10,3]}$ The values are similar to the $0.360 \pm 0.030$ and $0.346 \pm 0.006 \mathrm{~L} \mathrm{CH}_{4} \mathrm{~g}^{-1} \mathrm{VS}_{\text {added }}$ found for Winter wheat at the medium milk and soft dough stages respectively, and slightly higher than the reported value of $0.311 \pm 0.016 \mathrm{~L} \mathrm{CH}_{4} \mathrm{~g}^{-1} \mathrm{VS}_{\text {added }}$ for an alkalage-treated Winter wheat. ${ }^{[8]}$ 
Specific methane production during the BMP test was modelled using a pseudo-parallel first order equation known to give a good fit for solid organic wastes and energy crops.

${ }^{[25]}$ For this model the methane yield is given by Equation 1:

$Y=Y_{m}\left(1-P e^{-k_{1} t}-(1-P) e^{-k_{2} t}\right)$

where $Y$ is cumulative methane production at time $\mathrm{t} ; Y_{m}$ is the ultimate methane yield; $k_{l}$ is the first order rate constant for the proportion of readily degradable material; $k_{2}$ is the first order rate constant for less readily degradable material; and $P$ is the proportion of readily degradable material. Table 2 shows the results for Spring wheat.

BMP values and kinetic coefficients obtained for the treated and untreated Spring wheat were similar but were marginally less favourable in the case of Wheat 1 (as shown by lower values of $k_{1}, k_{2}$ and $P$ ), indicating that the additive used had no beneficial effect; values for Wheat 2 were therefore used in further calculations. Results for Winter wheat are shown in Table 3. For Winter wheat the values achieved for $k_{1}$ and $k_{2}$ were higher than those achieved for both Spring wheat indicating that Winter wheat degradation was faster than Spring wheat degradation.

\section{Energy potentials of Spring and Winter wheat}

The energy inputs into the growth of Spring and Winter wheat were calculated as 3721 and $3941 \mathrm{MJ} \mathrm{ha}^{-1}$ respectively, with the only differences between the two crops being the number of sprayings and fertiliser applications.

Table 4 summarises values for some key energy production parameters. The theoretical methane yields for Spring (Wheat 2) and Winter (Wheat B) calculated from the Buswell equation ${ }^{[18]}$ were 0.494 and $0.440 \mathrm{~L} \mathrm{CH}_{4} \mathrm{~g}^{-1} \mathrm{VS}$ respectively: if compared with the 
measured BMP values these indicate $\sim 73 \%$ and $\sim 79 \%$ VS breakdown (apparent substrate degradation) in the BMP test. This is within the range of VS destruction calculated from the residual solids concentration at the end of the BMP test, and thus supports the test results. Both of these wheats were ensiled. The theoretical calorific values or calculated $\mathrm{CV}$ of the two wheat samples, 19.9 and $17.9 \mathrm{MJ} \mathrm{kg}^{-1} \mathrm{VS}$, showed good agreement with the measured values, confirming the results of the elemental analysis. ${ }^{[19]}$ The energy recovery as methane thus corresponds to $72.3 \%(79.0 \%)$ and $77.0 \%(81.5 \%)$ of the theoretical (measured) CV values for Spring and Winter wheat respectively.

Based on BMP values and crop tonnages the potential energy yields for the Spring and Winter wheat crops when harvested at the same (soft dough) growth stage were 4456 and $4936 \mathrm{~m}^{3} \mathrm{CH}_{4} \mathrm{ha}^{-1}$ year $^{-1}$ respectively, equivalent to 177.5 and $196.7 \mathrm{GJ}^{-1} \mathrm{ha}^{-1}$ These compare favourably with the required input energy of 3.7 and $3.9 \mathrm{GJ} \mathrm{ha}^{-1}$ when using slurry as the fertiliser. Substituting the slurry with digestate would also be possible, as the TKN values (Table 1) indicate that digestates from Spring and Winter wheat could theoretically supply 263 and $197 \mathrm{~kg} \mathrm{~N} \mathrm{ha}^{-1}$, which is more than the amount required for cultivation. As the application methods for digestate are similar to those for slurry, there would be little change in the energy balance. Despite the higher energy demands for cultivation of Winter wheat and its slightly lower BMP than Spring wheat, its net energy yield was more favourable because of the higher dry matter yield on harvest. While Winter wheat had a slightly higher net energy yield than Spring wheat in the present study, both are suitable as energy crops and there are some advantages in being able to choose between them. Farming practice can be adapted to location, climate and annual variability in the weather, and the two varieties provide flexibility in sowing and harvesting periods. In some years weather conditions may prevent autumn sowing, or an 
adverse winter may kill autumn-sown seedlings. In these situations Spring wheat can be sown, with only a small reduction in overall energy yield. Spring wheat may also offer other potential advantages for energy production, as it leaves the fields free during autumn and winter to grow additional catch crops such as forage rape (Brassica napus) or mustard (Sinapsis alba), which can also be used as digester feedstock. ${ }^{[14]}$ The only risk is if poor weather delays the harvest and thus the sowing of a subsequent crop: in this case it may be beneficial to harvest a slightly immature Spring wheat, with any losses compensated for by the additional biomass yield from the catch crop.

\section{Digestate quality}

Anaerobic digested residues has beneficial effects on crops. Crop yields are generally higher following fertilizacion with digested sludge. ${ }^{[26]}$

In the UK, the acceptability of digestate for land application is regulated by PAS110 which defines limits on the concentration of potentially toxic elements on a TS basis. ${ }^{[27]}$ The metals concentration in digestate from semi-continuous digestion of Spring and Winter wheat can be estimated from the feedstock concentration and the predicted VS destruction. Although the original metals concentration is low, the final digestate concentration would exceed PAS110 limit values for Cd in the Spring wheat and for Cr, $\mathrm{Ni}$ and $\mathrm{Zn}$ in the Winter wheat: this mainly reflects the high degree of VS breakdown achieved, and confirms the inadequacy of standard for metals concentration based on the TS content rather than on wet weight of digestate applied.

\section{Conclusion}

In the current trial Spring wheat was found to have a specific methane potential of 0.36 $\mathrm{L} \mathrm{CH}_{4} \mathrm{~g}^{-1} \mathrm{VS}$ at the soft dough stage with a biomass yield of 13.0 tonnes $\mathrm{TS} \mathrm{ha}^{-1}$ year ${ }^{-1}$, 
making it a suitable crop to consider for energy production through anaerobic digestion. In this study, the lower energy requirements for cultivation and the higher specific methane potential of Spring wheat did not outweigh the better net energy yield of Winter wheat resulting from its higher biomass yield per hectare. The energy disadvantage of Spring wheat was small, however, cultivation of this crop can also offer a second opportunity to provide an energy-rich substrate with a good yield in cases where the winter crop has failed or weather conditions prevent autumn sowing. A further advantage of Spring wheat is that it may allow growth of a spring-harvested over-winter catch crop, increasing the overall annual biomass productivity and the energy yield per hectare.

\section{Acknowledgements}

This research was part-funded by the UKRC RELU project RES 229-25-0022. The authors are grateful to the Secretaría de Estado de Universidades e Investigación from the Spanish Education and Science Ministry and the Fundación Española para la Ciencia y la Tecnología (FECYT) for supporting Dr Rincón. Thanks are due to Peter King of KingBros for supplying wheat samples and crop information, and Dr Yue Zhang of the University of Southampton for advice on interpretation of analytical data.

\section{References}

[1] Zhou, H.; Li, H.; Wang, F. Anaerobic digestion of different organic wastes for biogas production and its operational control performed by the modified ADM1. J. Environ. Sci. Health, Part A. 2012, 47, 84-92. 
[2] Appels, L.; Joost, L.; Degreve, J.; Helsen, L.; Lievens, B.; Willems, K.; Van Impe, J.; Dewil, R. Anaerobic digestion in global bio-energy production: potential and research changes. Renew. Sust. Energ. Rev. 2011, 15, 4295-4301.

[3] Deublein, D.; Steinhauser, A. Biogas from waste and renewable resources. $1^{\text {st }}$ ed. Weinheim: Wiley-VCH; 2008.

[4] European Union (EU). Directive 2009/28/EC of the European Parliament and of the Council of 23343 April 2009. Official Journal of the European Union 2009, L140, $16-62$.

[5] Pakarinen, O.; Lehtomaki, A.; Rissanen, S.; Rintala, J. Storing energy crops for methane production: effects os solids content and biological additive. Bioresource Technol. 2008, 99, 7074-7082.

[6] Pakarinen, A.; Maijala, P.; Jaakkola, S.; Stoddard, F.L.; Kymäläinen, M.; Viikari, L. Evaluation of preservation methods for improving biogas production and enzymatic conversion yields of annual crops. Biotechnol. Biofuels. 2011, 4, 1-20.

[7] Yang, X.; Chen, H.; Gao, H.; Li, Z. Bioconversion of corn straw by coupling ensiling and solid-state fermentation. Bioresource Technol. 2001, 78, 277-280.

[8] Rincón, B.; Banks, C.J.; Heaven, S. Biochemical methane potential of winter wheat (Triticum aestivum L.): Influence of growth stage and storage practice. Bioresource Technol. 2010, 101, 8179-8184.

[9] Herrmann, C.; Heiermann, M.; Idler, C. Efects of ensiling, silage aditives and storage period on methane formation of biogas crops. Bioresource Technol. 2011, $102,5153-5161$.

[10] Amon, T.; Amon, B.; Kryvoruchko, V.; Machmüller, A.; Hopfner-Sixt, K.; Bodiroza, V.; Hrbek, R.; Friedel, J.; Pötsch, E.; Wagentristl, H.; Schreiner, M.; Zollitsch, W. Methane production through anaerobic digestion of various energy 
crops grown in sustainable crop rotations. Bioresource Technol. 2007, 98, 32043212.

[11] Karpenstein-Machan, M. Energiepflanzenbau für Biogasanlagenbetriber, Frankfurt, Verlag, 2005.

[12] Pouech, P.; Fruteau, H.; Bewa, H. Agricultural Crops for Biogas Production on Anaerobic Digestion Plants. Biomass for Energy and Industry, C.A.R.M.E.N. Proceeding of the International Conference, Würzburg, Germany, 2008.

[13] Weiland, P. Production and Energetic Use of Biogas from Energy Crops and Wastes in Germany. Appl. Biochem. Biotechnol. 2003, 109, 263-274.

[14] Molinuevo-Salces, B.; Larsen, S.U.; Ahring, B.K.; Uellendahl, H. Biogas production from catch crops: evaluation of biomass yield and methane potential of catch crops in organic crop rotations. Biomass Bioenerg. 2013, 59, 285-292

[15] Loomis, R.S.; Connor, D.J. Crop Ecology: Productivity and Management in Agricultural Systems, Cambridge University Press: Cambridge, UK, 1992.

[16] Walker, M.; Zhang, Y.; Heaven, S.; Banks, C.J. Potential Errors in the Quantitative evaluation of Biogas Production in Anaerobic Digestion Processes. Bioresource Technol. 2009, 100, 6339-6346.

[17] APHA. Standard Methods for the Examination of Water and Wastewater. 21st Ed. Washington DC, USA: American Public Health Association/American Water Works Association/Water Environment Federation, 2005.

[18] Symons, G.E.; Buswell, A.M. The Methane Fermentation of Carbohydrates. J. Americ. Chem. Soc. 1933, 55, 2028-2036.

[19] IFRF. International Flame Research Foundation Online Combustion Handbook. ISSN 1607-9116. http://www.handbook.ifrf.net/handbook/, accessed April 2011. 
[20] Salter, A.; Banks, C.J. Establishing an energy balance for crop-based digestion. Water Sci. Technol. 2009, 59, 1053-1060.

[21] KTBL. Betriebsplannung Landwirtschaft 2008/09, Darmstadt, KTBL. 2009.

[22] Berglund, M.; Börjesson, P. Assessment of energy performance in the life-cycle of biogas production. Biomass Bioenerg. 2006, 30, 254-266.

[23] Audsley, E.; Pearn, K.R.; Simota, C.; Cojocaru, G.; Koutsidou, E.; Rounsevell, M.D.A.; Trnka, M.; Alexandrov, V. What can scenario modelling tell us about future European scale agricultural land use and what not? Environ. Sci. Policy 2006, $9,148-162$.

[24] AEA. Guidelines to Defra/DECC's GHG Conversion Factors for Company Reporting. Department for Environment Food and Rural Affairs, London, 2010.

[25] Rao, M.S.; Singh, S.P.; Singh, A.K.; Sodha, M.S. Bioenergy conversion studies of the organic fraction of MSW: Assessment of ultimate bioenergy production potential of municipal garbage. Appl. Energ. 2000, 66, 75-87.

[26] Shi, Y.; Lu, Y.; Liang, D. Application of anaerobic digested residues on safe food production. J. Environ. Sci. Health, Part A. 2002, 37(4), 725-735.

[27] BSI. PAS 110:2010. Specification for whole digestate, separated liquor and separated fibre derived from the anaerobic digestion of source-segregated biodegradable materials. BSI, Milton Keynes, UK, 2010. 


\section{FIGURE CAPTIONS}

Figure 1. Cumulative net specific methane production in Spring wheat BMP test, showing experimental results and kinetic model output. Wheat 1.1., Wheat 1.2 and Wheat 1.3 are the three replicates assayed for Wheat 1, and Wheat 2.1., Wheat 2.2 and Wheat 2.3 are the three replicates assayed for Wheat 2. 
Table 1 Spring wheat, Winter wheat and inoculum characterisation.

\begin{tabular}{|c|c|c|c|c|c|c|c|}
\hline & \multirow[t]{2}{*}{ Unit } & \multicolumn{2}{|c|}{ Spring wheat } & \multicolumn{3}{|c|}{ Winter wheat } & \multirow[b]{2}{*}{ Inoculum } \\
\hline & & $\begin{array}{c}\text { Wheat } \\
1\end{array}$ & $\begin{array}{c}\text { Wheat } \\
2\end{array}$ & Wheat $\mathbf{A}^{\mathrm{a}}$ & Wheat $\mathbf{B}^{\mathbf{a}}$ & Wheat $C^{a}$ & \\
\hline Treatment & & $\begin{array}{c}\text { Silage } \\
+ \\
\text { additive }\end{array}$ & Silage & Silage & Silage & Alkalage & - \\
\hline $\mathrm{pH}^{\mathrm{b}}$ & & 4.4 & 4.2 & 4.2 & 4.1 & 8.3 & 8.1 \\
\hline TKN & $\begin{array}{l}\mathrm{g} \mathrm{N} \mathrm{kg}^{-1} \\
\text { WW }\end{array}$ & 8.1 & 8.2 & 6.4 & 7.0 & 17.0 & - \\
\hline Ammonia & $\begin{array}{l}\mathrm{g} \mathrm{N} \mathrm{kg}^{-1} \\
\text { WW }\end{array}$ & 2.2 & 2.2 & 1.3 & 1.8 & 5.6 & - \\
\hline $\mathrm{TS}$ & $\mathrm{g} \mathrm{kg}^{-1} \mathrm{WW}$ & 392 & 404 & 363 & 525 & 835 & 38.5 \\
\hline VS & $\mathrm{g} \mathrm{kg}^{-1} \mathrm{WW}$ & 373 & 384 & 347 & 513 & 811 & 24.4 \\
\hline Moisture & $\%$ & 60.8 & 59.8 & 63.4 & 47.5 & 16.5 & - \\
\hline $\mathrm{CV}$ & $\mathrm{kJ} \mathrm{g}^{-1} \mathrm{VS}$ & 18.0 & 18.2 & 17.0 & 16.9 & 16.7 & - \\
\hline $\mathrm{P}$ & $\mathrm{g} \mathrm{kg}^{-1} \mathrm{WW}$ & 1.13 & 1.20 & 0.74 & 0.84 & 1.77 & - \\
\hline $\mathrm{K}$ & $\mathrm{g} \mathrm{kg}^{-1} \mathrm{WW}$ & 3.79 & 4.00 & 4.88 & 5.52 & 6.38 & - \\
\hline $\mathrm{Cd}$ & $\mu \mathrm{g} \mathrm{g}^{-1} \mathrm{TS}$ & 0.99 & 1.01 & 0.40 & 0.15 & 0.98 & - \\
\hline $\mathrm{Cr}$ & $\mu \mathrm{g} \mathrm{g}^{-1} \mathrm{TS}$ & 33.6 & 16.7 & 104.4 & 66.7 & 37.4 & - \\
\hline $\mathrm{Cu}$ & $\mu \mathrm{g} \mathrm{g}^{-1} \mathrm{TS}$ & 7.0 & 10.5 & 37.9 & 9.8 & 62.9 & - \\
\hline $\mathrm{Ni}$ & $\mu \mathrm{g} \mathrm{g}^{-1} \mathrm{TS}$ & 16.9 & 6.7 & 35.6 & 25.5 & 17.0 & - \\
\hline $\mathrm{Pb}$ & $\mu g^{-1} \mathrm{TS}$ & 6.86 & 7.49 & 2.21 & - & 3.63 & - \\
\hline $\mathrm{Zn}$ & $\mu \mathrm{g} \mathrm{g}^{-1} \mathrm{TS}$ & 61.8 & 55.1 & 172.1 & 103.4 & 276.5 & - \\
\hline $\mathrm{C}$ & $\% \mathrm{VS}$ & 50.02 & 49.36 & 46.70 & 45.90 & 46.24 & - \\
\hline $\mathrm{N}$ & $\% \mathrm{VS}$ & 1.86 & 1.97 & 1.73 & 1.48 & 2.08 & - \\
\hline $\mathrm{H}$ & $\% \mathrm{VS}$ & 6.89 & 6.90 & 6.61 & 6.56 & 6.63 & - \\
\hline
\end{tabular}


Table 2 Spring wheat BMP values and model coefficients for wheat 1 (tested in triplicate wheat 1.1 , wheat 1.2 and wheat 1.3 ) and wheat 2 (tested in triplicate wheat 2.1, wheat2.2 and wheat 2.3). $Y_{m}$ is the ultimate methane yield; $k_{l}$ is the first order rate constant for the proportion of readily degradable material; $k_{2}$ is the first order rate constant for less readily degradable material; and $P$ is the proportion of readily degradable material.

\begin{tabular}{lccccccc}
\hline & Unit & Wheat & Wheat & Wheat & Wheat & Wheat & Wheat \\
& & $\mathbf{1 . 1}$ & $\mathbf{1 . 2}$ & $\mathbf{1 . 3}$ & $\mathbf{2 . 1}$ & $\mathbf{2 . 2}$ & $\mathbf{2 . 3}$ \\
\hline $\boldsymbol{Y}_{\boldsymbol{m}}$ & $\mathrm{L} \mathrm{CH}_{4} \mathrm{~g}^{-1} \mathrm{VS}_{\text {added }}$ & 0.348 & 0.348 & 0.356 & 0.359 & 0.358 & 0.365 \\
$\boldsymbol{P}$ & - & 0.67 & 0.67 & 0.71 & 0.71 & 0.70 & 0.71 \\
$\boldsymbol{k}_{\boldsymbol{1}}$ & day $^{-1}$ & 0.76 & 0.70 & 0.70 & 0.74 & 0.79 & 0.74 \\
$\boldsymbol{k}_{\mathbf{2}}$ & day $^{-1}$ & 0.05 & 0.06 & 0.03 & 0.05 & 0.06 & 0.06 \\
${ }^{\mathbf{a}} \mathbf{R}^{\mathbf{2}}$ & & 0.9980 & 0.9983 & 0.9958 & 0.9981 & 0.9977 & 0.9975 \\
\hline
\end{tabular}

${ }^{\mathrm{a}}$ correlation coefficient for experimental data and model output

Table 3 Winter wheat BMP values and model coefficients for wheat A, B and C. $Y_{m}$ is the ultimate methane yield; $k_{1}$ is the first order rate constant for the proportion of readily degradable material; $k_{2}$ is the first order rate constant for less readily degradable material; and $P$ is the proportion of readily degradable material.

\begin{tabular}{lcccc}
\hline & Unit & Wheat A & Wheat B & Wheat C \\
\hline $\boldsymbol{Y}_{\boldsymbol{m}}$ & $\mathrm{L} \mathrm{CH}_{4} \mathrm{~g}^{-1} \mathrm{VS}_{\text {added }}$ & 0.360 & 0.346 & 0.311 \\
$\boldsymbol{P}$ & - & 0.67 & 0.64 & 0.63 \\
$\boldsymbol{k}_{\boldsymbol{1}}$ & day $^{-1}$ & 0.78 & 0.83 & 0.67 \\
$\boldsymbol{k}_{2}$ & day $^{-1}$ & 0.07 & 0.077 & 0.08 \\
$\boldsymbol{R}^{2}$ & & 0.9987 & 0.9987 & 0.9990 \\
\hline
\end{tabular}

${ }^{a}$ Data from Rincón et al. ${ }^{[8]}$ 
Table 4 Energy values for Spring and Winter wheat

\begin{tabular}{llcc}
\hline & Unit & Spring wheat & Winter wheat \\
\cline { 2 - 4 } $\mathrm{CH}_{4}$ yield in BMP & $\mathrm{L} \mathrm{g}^{-1} \mathrm{VS}$ & 0.361 & 0.346 \\
Empirical formula & & $\mathrm{C}_{4.11} \mathrm{H}_{6.84} \mathrm{O}_{2.61} \mathrm{~N}_{0.14}$ & $\mathrm{C}_{3.82} \mathrm{H}_{6.51} \mathrm{O}_{2.88} \mathrm{~N}_{0.11}$ \\
Theoretical $\mathrm{CH}_{4}$ yield (Buswell) & $\mathrm{L} \mathrm{g}^{-1} \mathrm{VS}$ & 0.494 & 0.440 \\
Theoretical methane content & $\%$ & 53.6 & 51.4 \\
Apparent substrate destruction & $\%$ & 73 & 79 \\
Calculated CV (Du Long) & $\%$ & 19.9 & 17.9 \\
Measured CV & $\mathrm{MJ} \mathrm{kg}^{-1} \mathrm{VS}$ & 18.2 & 16.9 \\
Energy recovered as $\mathrm{CH}_{4}{ }^{\mathrm{b}}$ & $\mathrm{MJ} \mathrm{kg}^{-1} \mathrm{VS}$ & 14.4 & 13.8 \\
Recovery of measured CV as & $\%$ & 79.0 & 81.5 \\
Recovery of calculated CV as & $\%$ & 72.3 & 77.0 \\
Biomass yield & $\mathrm{MJ} \mathrm{kg}^{-1} \mathrm{VS}$ & 12.36 & 14.46 \\
Gross methane production & tonnes VS ha $^{3}$ ha $^{-1}$ year $^{-1}$ & 4456 & 5004 \\
Gross energy yield & $\mathrm{GJ} \mathrm{ha}^{-1}$ year $^{-1}$ & 177.5 & 199.3 \\
\hline
\end{tabular}

${ }^{a}$ Based on actual methane yield divided by theoretical

${ }^{\mathrm{b}}$ Based in higher heat value $=39.84 \mathrm{MJ} \mathrm{m}^{-3} \mathrm{CH}_{4}$

CV: Calorific Value, VS: Volatile Solids.

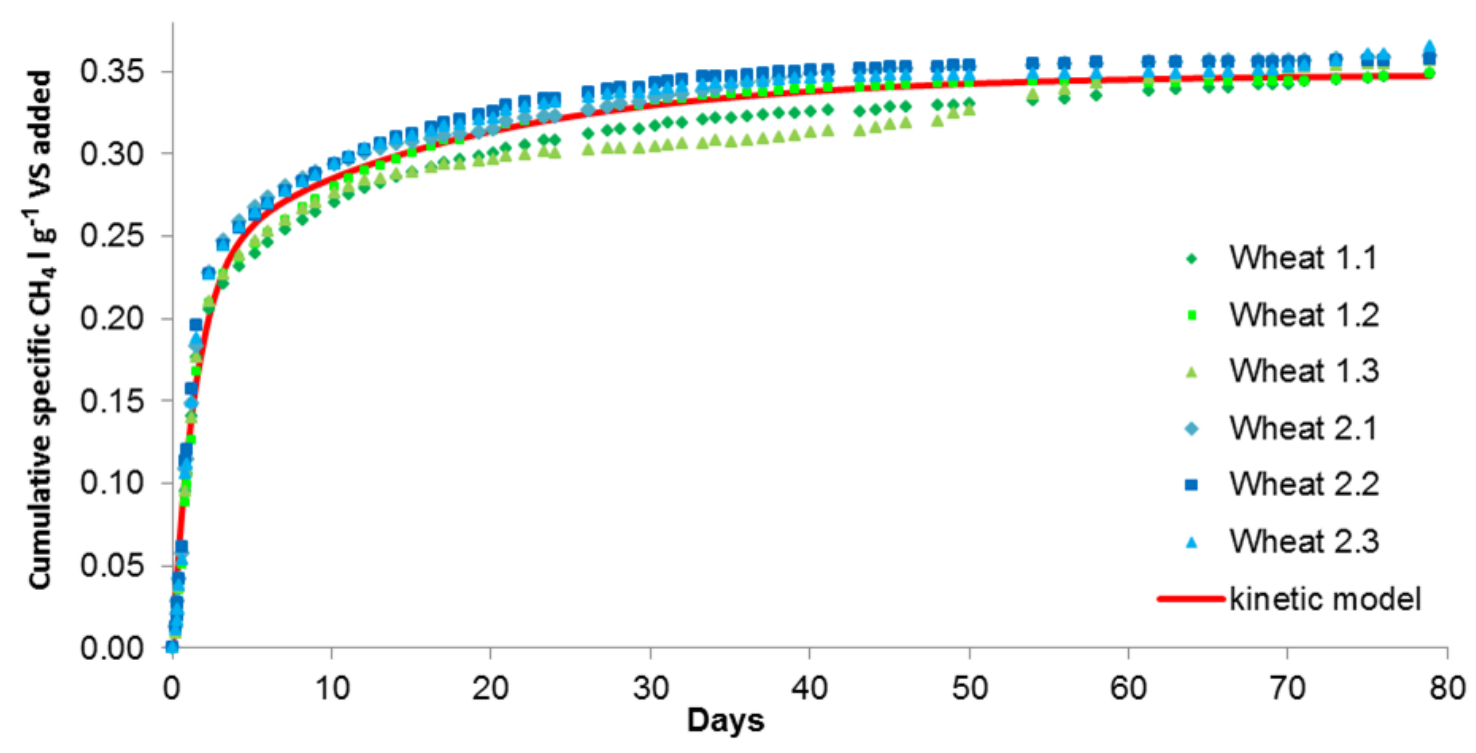

Fig.1 